\title{
INCONCINNITY PURSUED: THE SECRET OF SOSIA AND RELATED MATTERS
}

\author{
James R. Stamm \\ New York University
}

\begin{abstract}
In an earlier paper, I examined three troublesome cases of jointure in the continuation of Act XIV of the Tragicomedia; moments in which the continuator of the Comedia seems to lose track of the sense of the text he is amplifying. 1 My third point referred to Calisto's soliloquy of self-examination in which he asks.himself: "¿Por qué no sali a inquirir la verdad de la secreta causa de mi manifiesta perdición?" 2 It is obvious from the text of Act XIII that the murder is quite literally out and that all details have been made excruciatingly public, first by the pregón of the "cruel verdugo" and immediately after in more affective terms, proclaimed by Elicia to all who would hear-and present in her audience, Sosia. There simply is no "secreta causa" in the decease of Celestina and the punishment of her assassins, yet the continuator seems obsessed by this idea. He makes it a theme in the acts which compose the nucleus of the Tratado de Centurio. ${ }^{3}$
\end{abstract}

In Act XV, Areúsa proposes a plan to take vengeance on Calisto and Melibea for the multiple deaths. This is a complex and sophisticated concept which the slow-witted Elicia does not grasp at once, but when it is spelled out to her, she is convinced that the stratagem will not work: "No habrá efecto lo que quieres, porque la pena de los que murieron por descubrir el secreto porná silencio al vivo [Sosia] para guardarle" (203). We seem most unexpectedly to be in some sort of Sicilian situation ruled by the law of omertà. He who tells the secret shall die! But what secret? Certainly no one in the comedia is in a better position than Elicia to know the straight-forward facts of this vulgar dispute and its fatal consequences.

The mystery compounds. Following the interruption in the action of the Tratado which Act XVI represents, Areusa spins her web for sosia. It is her pretense to warn the ingenuous rascacaballos against tattlers and spies; "avisarte que te guardes de peligros $v$ más de descubrir tu secreto a ninguno, pues ves cuánto daño vino a Pármeno y a Sempronio de 10 que supo Celestina" (XVII, 211). What did Celestina know that caused the mortal plunge of Parmeno and Sempronio? Weren't we there to hear the whole thing? It turns out that the only secret sosia is able to impart is the hour of Calisto's assignation and the route they will take, "por la calle del vicario gordo, a las espaldas de su 
casa (de Melibea]" (212). Elicia was wrong; Sosia feels no chill shudder of impending doom in revealing his momentous secret.

The theme of the secret is ridiculed and reduced to farse in Act XVIII. Centurio reveals in an offhand way that he is fully aware of the Calisto/Melibea liaison, even down to the details the mochachas have conspired at such length to learn from Sosia. "Todo el negocio de sus amores sé y los que por su causa hay muertos $y$ lo que os tocaba a vosotras, por dónde va y a qué hora y con quién es" (215). Centurio, surely not the most prudent of the local low-life, has no particular reason to have unearthed this information; the whole affair must be common knowledge, and the cousins might just as easily have picked up the gossip in the nearest tavern, without resorting to an elaborate ruse involving Sosia. Calisto's earlier fears are now confirmed: "iOh mis secretos más secretos, cuán públicos andaréis por las plazas Y mercados!" (XIII, 188). Yet we must distinguish a point that the author of the Tratado has left in confusion: there are in fact two sets of "secrets" in play here. One, the schedule and itinerary of Calisto's nocturnal sallies turns out to be no secret at all (and the scheme of Areúsa is shown to have been a total waste of time). The other secret, related to some mysterious knowledge--"lo que supo Celestina"--which caused the deaths of Pármeno and Sempronio--is never resolved or explained.

We may suppose that the continuator is indulging a sense of comedy in setting up an elaborate structure of intrigue in which Areúsa worms Sosia's secret from him by flattery and a show of concern for his well-being, only to reduce it all to inconsequential rubble in Act XVIII. This is not consonant with the humor of either the first author or Rojas; this is not the way the mind of either of them works. No example comes to mind in the Auto or in the Comedia in which a complex line of action, involving considerable planning and textual space, is subsequently annulled and shown to be a pointless waste of time. 4

\begin{abstract}
A second example of inconcinnity concerns the distribution of chronological time in the Tratado. The public mandate which governs this interpolation, "hallé que querian que se alargase en el proceso de su deleite de estos amantes, sobre lo cual fui muy importunado" (Prólogo, 4344), will oblige the author to extend the temporal duration of the affair. He decides that a month will be about right, but then the problem arises, where to tuck in this additional period?
\end{abstract}

Act XV follows directly upon the new ending of Act XIV, in which Sosia observes Elicia, dressed in mourning, making her way to the house of Areúsa. It is four o'clock in the afternoon--a Thursday, Areusa will later inform us--of the 
day following Calisto's seduction of Melibea. At this time, the cousins hatch their plot to dupe sosia into revealing his secret and Elicia goes off to put the plan into effect: "De lo dicho me llevo el cargo" (XXX). The scene now shifts to Pleberio's house for Act XVI, interrupting the line of action we have been following. Melibea hammers home the fact that her meetings with Calisto have gone on for a month; three times in one speech she uses the expression "un mes ha," ending with the declaration, "Y después un mes ha, como has visto, que jamás noche ha faltado sin ser nuestro huerto escalado como fortaleza..." (206). Thus a month of trysts has passed between Act XV and Act XVI.

We are again with the vengeful mochachas in Act XVII as Elicia returns to the house of Areúsa, apparently for the first time since "el otro día cuando le llevé las noticias de este triste negocio" (208). Her arrival coincides with that of Sosia in his first appearance at Areúsa's behest. The stable-boy will confirm the time lapse, although his account differs slightly from that of Melibea: "En un mes no habemos ido ocho veces." Thus the problem arises: did Elicia delay a month in getting the message to Sosia that Areúsa would like a word with him? or did the rascacaballo.s react very, very slowly to the information that "una hermosa mujer, muy graciosa Y fresca, enamorada, medio ramera" (XIV, 197), as he describes her, had taken an active interest in meeting with him to discuss his personal welfare? The alternatives seem equally unlikely; we are left with an unseemly and unexplained gap in one important element of the action of the Tratado. Areusa compounds this impression of inconcinnity when she now recalls the beginning of Act XV with a reference to "aquel otro cara de ahorcado [Centurio] que el jueves eché delante de ti baldonado de mi casa" (XVII, 213). It is not usual to refer to an event which took place a month earlier by recaling the day of the week on which it happened, unless the day itself has special significance or one is trying to be quite specific. Areusa is simply recalling the occasion for Elicia, not insisting on extreme precision.

It is no easy undertaking to introduce and intercalate a month of elapsed time into a work so dense, so closed, as the Comedia. Rojas encountered a similar problem in his attempt to separate the first scene of the Auto from the action which follows, and he handles the self-imposed challenge with more elegance. We find in the Tratado what amounts, in artistic terms, to a display of brute force. No real attempt is made to reknit the resulting frayed edges. The Antiguo Auctor is able to suspend time indefinitely while Pármeno spins out the symphony of Celestina and the catalog of ner botica and, again later, in the dialogue between Pármeno and the bawd. Rojas creates a problem for himself which he can only solve by repeated reference, in act after act, to "el otro dia" for the first encounter 
between Calisto and Melibea, in a sequence of action that flows unbroken in the comedia from the first cries of "isempronio, Sempronio, Sempronio!" to "in hac lachrymarum valle." The author of the Tratado displays little creative effort and less sense of logical sequence in structuring his invented month of pleasure for the lovers and of contemplated vengeance for the mochachas.

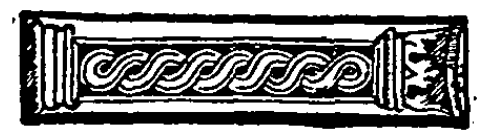

NOTES

I"Inconcinnity in the Tragicomedia, Act XIV," Celestinesca, 8:i (1984), 43-46.

2 All references to the text follow La Celestina, ed. Dorothy S. Severin (Madrid: Alianza Editorial, 8 th ed., 1981). Act and page of quotations are indicated in the text. For this reference, XIV, 193.

3 our terminology for the expanded version of Celestina is inexact and confusing in the extreme. For the Tratado de Centurio. I understand the new ending of act XIV, acts XV, XVII, XVIII, and the first scene of act XIX, the dialogue between Sosia and Tristán. Miguel Marciales offers a provoking analysis of the text in his famous "Carta al Profesor Gilman," now republished as Sobre problemas rojanos $y$ celestinescos (Mérida, Venezuela: Universidad de los Andes, 1983), especially pp. 48-64.

${ }^{4}$ There is, of course, celestina's change of strategy in her handling of the "negocio" from the Auto to act $V$ of the Comedia. Her original plan, to prolong Calisto's agony as far as possible--"alargarle he la certenidad del remedio, porque como dicen, el esperanza luenga aflige el corazón y cuanto él perdiere, tanto gela promete. iBien me entiendes!" ( $I$, 58-59)--undergoes radical change, to Sempronio's surprise. Celestina explains: "El propósito muda el sabio; el necio persevera.... No pensé yo, hijo Sempronio, que así me respondiera mi buena fortuna.... Más dará Calisto en un día de buenas nuevas, que en ciento que ande penando $\underline{y}$ vo yendo $y$ viniendo." (V, 104). Rojas very sensibly alters the original structure, which threatened to drag out the action, but we note that the alteration is quite logically motivated and presented as a planned revision in Celestina's assessment of the project. 